\title{
BULLETIN OF THE
}

\section{AMERICAN}

\section{MATHEMATICAL SOCIETY}

\author{
A Historical and Critical Review \\ of Mathematical Science
}

EDITED BY

$\begin{array}{lll}\text { F. N. COLE ALEXANDER ZIWET } & \text { D. E. SMITH }\end{array}$ FRANK MORLEY VIRGIL SNYDER

$\begin{array}{ll}\text { J. W. YOUNG } & \text { W. B. FORD }\end{array}$

\section{VOI. XIII}

OCTOBER 1906 TO JULY 1907

PUBLISHED FOR THE SOCIETY BY THE MACMILLAN COMPANY

Lancaster, Pa., AND New York 1907 
PRess of

The new era printing company Lancaster, Pa. 


\title{
BULLETIN
}

\author{
OF THE
}

\section{AMERICAN}

\section{MATHEMATICAL SOCIETY}

\author{
A Historical and Critical Review \\ of Mathematical Science
}

EDITEI $\mathbf{B Y}$
F. N. COLE
ALEXANDER ZIWET
D. E. SMITH

FRANK MORLEY

VIRGIL SNYDER

H. S. WHITE

Volume XIII., Number 1

OCTOBER, 1906

Published for the Society

By THE MACMILLAN COMPANY

LANCASTER, PA., AND NEW YORK 1906

Entered at the Post Office at Lancaster, Pa., as second-class matter PUblished MONThLy, mXokPt AUgust AND SkPtember 


\title{
Second Edition, Revised and Enlarged.
}

\section{MECH A N I CS PROBLEMS}

FOR ENGINEERING STUDENTS

BY

FRANK B. SANBORN

Member of American Society of Civil Engineers

Professor of Civil Engineering in Tufts College

Contents.-I. Work ; Foot pounđs; Horse-power; Energy. II. Force; Forces Acting at a point; Moments for Parallel Forces; Couples; Stresses; Center of Gravity ; Friction. III. Motion; Uniform Acceleration; Relative Velocity; Distance, Velocity, Friction, Angle of Inclination; Projectiles; Pendulums; Impact. Review: Practical Problems ; Examinations ; Answers; Definitions; Tables ; Index.

Large 12mo, viii + 194 pages, 100 figures. Cloth, $\$ 1.50$.

Order through your bookseller, or copies will be forwarded postpaid by the publishers on the receipt of the retail price.

\author{
NEW YORK \\ JOHN WILEY \& SONS \\ LONDON : CHAPMAN \& HALL, LIMITED
}

1906 